\title{
A Study on Occupational Aspiration Skill and Personality Traits of Institutionalized Adolescent Orphans in Kerala as Related to their Realistic and Idealistic Mode of Evaluation
}

Jyothy G Vijayan*† and Santhi S*ł

\begin{abstract}
The present trend suggests that students are pressurized by the society to select an occupation of their choice that can fetch easy money. That is why there is a heavy rush towards medicine, nursing, para-medical and engineering streams. This often negates the potential of each student and suppresses his or her innate caliber that negatively affects the prospects of the individual and society. The choice of occupation is one of the very important decisions a person makes in life. Psychologically each student has her/his own interests, aptitudes, attitudes, aspirations etc. It is a fact that parents, relatives, teachers, friends, media and society can influence the students in the modification of interests, aptitudes, attitudes, aspirations etc. If a person gets her/his education on their preferred vocation, he/she can get job satisfaction from the vocation and the individual shall be well placed. Aspirations add to the efficiency of the person by bringing out the best in him on the job.
\end{abstract}

\footnotetext{
* Mar Severios Memorial College of Teacher Education, Chengaroor, MG University, Kerala; India; ${ }^{\dagger}$ jyoparu@gmail.com

‡ Santhis@gmail.com
} 
Keywords: Occupational aspiration scale, long and short range career aspiration

\section{Introduction}

Educating a child means directing the child properly in the various phases of life. Education is emancipation form ignorance. According to H.G. Wells one could define education as the lifting of the mind out of blind alleys. Institutionalized children are one of the groups of child population who are affected by various forms of deprivation, the most important being the absence of an intimate, consistent interaction with an adult figure. Their basic need for individual care, attention, love, warmth, security etc. are not adequately met in institutions and as a result, the children grow up with poor mental health and adjustment problems.

The decision to choose an occupation is very important one in the life of a person. This choice is not a simple incident. It is the result of a long sociological and academic process. Occupational interests and choices do not appear as a part of Personality formation process during adolescence [1-3]. Occupational Aspiration is a continuous and ongoing process. Teachers can of course play a major role in influencing the decision making process of a student in terms of their choice of occupation. Teachers can guide the students according to their abilities and talents[4].

A child's knowledge, values, skills, attitudes and aspirations are bound to change throughout the process of education[5].Some Adolescent Orphans know how they like to improve their personalities and have strong motivation to do so. But they do not know how to go about it. When they go out into the adult world, they realize that a good Personality not only leads to popularity but that it is often the most important factor in business, profession etc. This increases their desire to improve their personalities [6-8].

Individuality refers to the uniqueness in Personality. According to Allport, "Personality itself is a universal phenomenon though it is found only in individual form". A person "has many attributes characteristic of the human species, and many that resemble his cultural fellows but he weaves them all into a unique idiomatic 
Jyothy and Santhi Occupational Aspiration Skill and Personality Traits

system. Individuality in the Personality pattern is just as characteristic as is individuality in appearance. Each person is a unique and never-repeated phenomenon [9-10].

\section{Objectives of the Study}

1. To find out the correlation between personality traits and variables of occupational aspiration skills of Institutionalized Adolescent Orphans.

2. To find out the correlation between boys and girls in component-wise occupational aspiration skills

3. To find out the correlation between rural and urban orphans in component wise occupational aspiration skill

4. To find out the correlation between boys and girls in component-wise personality traits.

5. To find out the correlation between rural and urban orphans in component wise personality traits

\section{Hypotheses of the Study}

1. There is no significant correlation between personality traits and the variables of Occupational Aspiration skill of Institutionalized Adolescent Orphans.

2. There is no significant correlation between boys and girls in component wise occupational aspiration skills

3. There is no significant correlation between rural and urban orphans in component wise occupational aspiration skills

4. There is no significant correlation between boys and girls in component wise personality traits

5. There is no significant correlation between rural and urban orphans in component wise personality traits 


\section{Research Methodology}

\section{Sample Size}

\section{Sample of the Study}

The sample for the present study constituted 250 institutionalized adolescent orphans belonging to different districts. The sample contains 125 boys and 125 girls, adolescent orphans from 13 orphanages. The sample was also further divided into 125 orphans from rural orphanages and 125 orphans from urban orphanages in Kottayam, Pathanamthitta, Eranakulam, Alppuzha, and Malappuram districts.

\section{Tools Used in the Study}

1. Occupational aspiration scale, by Dr. J.S Grewal.

2. Personality Inventory, standardized by H.J. Eyesenck.

\section{Statistical Techniques employed in the study}

Multiple regression analysis was employed in the present study.

\section{Findings and Discussions}

Comparison of Personality Traits and Variables of Occupational Aspiration

$\mathrm{H}_{0}$ :There is no significant correlation between the variables of Occupational Aspiration skill and personality traits of Institutionalized Adolescent Orphans.

Table 1Data and Result of Test of Significance between Personality Traits and variables of Occupational Aspiration

\begin{tabular}{|c|c|c|c|c|c|}
\hline Variables & $\mathrm{N}$ & Df & $\mathrm{r}$ & $\operatorname{tr}$ & $\begin{array}{c}\text { Level of } \\
\text { Significance }\end{array}$ \\
\hline $\begin{array}{l}\text { Personality Traits } \\
\text { Realistic Short Range } \\
\text { Occupational } \\
\text { Aspiration }\end{array}$ & 250 & 248 & .055 & .861 & $\mathrm{P}>.05$ \\
\hline $\begin{array}{l}\text { Personality Traits } \\
\text { Idealistic Short Range } \\
\text { Occupational } \\
\text { Aspiration }\end{array}$ & 250 & 248 & .004 & .107 & $\mathrm{P}>.05$ \\
\hline
\end{tabular}


Jyothy and Santhi Occupational Aspiration Skill and Personality Traits

\begin{tabular}{llllll}
\hline $\begin{array}{l}\text { Personality Traits } \\
\text { Realistic Long Range }\end{array}$ & & & & & \\
Occupational & 250 & 248 & .113 & 2.99 & $\mathrm{P}<.05$ \\
Aspiration & & & & & \\
$\begin{array}{l}\text { Personality Traits } \\
\text { Idealistic Long Range }\end{array}$ & & & & & \\
Occupational & 250 & 248 & .057 & 1.54 & $\mathrm{P}>.05$ \\
Aspiration & & & & & \\
\hline
\end{tabular}

The $\mathrm{r}$ value .055 indicated slight positive correlation between Personality Traits and Realistic short range Occupational Aspiration. Hence it could be concluded that there is a slight positive correlation between Personality Traits and Realistic short Range Occupational Aspiration the obtained tr value (.861) is less than the table value (.2.34) at 0.01 level and (1.65) where $\mathrm{df}$ is 248 at .05 level of significance. So it can be inferred that there is no significant correlation between Personality Traits and Realistic Short Range Occupational Aspiration.

The $\mathrm{r}$ value -.004 indicated the negative correlation between Personality Traits and Idealistic Short Range Occupational Aspiration. Hence it could be concluded that there is a positive correlation between Personality Traits and Idealistic Short Range Occupational Aspiration. The obtained tr value (.107) is less than the table value(2.34) at 0.01 level and (1.65) where $\mathrm{df}$ is 248 at .05 level of significance. So it can be inferred that there is no significant correlation between Personality Traits and Idealistic Short Range Occupational Aspiration.

The $\mathrm{r}$ value .113 indicated the slight positive correlation between Personality Traits and Realistic Long Range Occupational Aspiration. Hence it could be concluded that there is a slight positive correlation between Personality Traits and Realistic Long Range Occupational Aspiration. The obtained tr value (2.99) is greater than the table value (2.34) at 0.01 level and it is greater than the table value (1.65) where $\mathrm{df}$ is 248 at .05 level of significance. So it can be inferred that there is a significant relationship between Personality Traits and Realistic Long Range Occupational Aspiration. 
The $\mathrm{r}$ value -.057 indicated the negative correlation between Personality Traits and Idealistic Long Range Occupational Aspiration. Hence it could be concluded that there is a negative correlation between Personality Traits and Idealistic Long Range Occupational Aspiration The obtained tr value (1.54) is less than the table value (2.34) at 0.01 level and it is less than the table value (1.65) where df is 248 at .05 level of significance. So it can be inferred that there is no significant relationship between Personality Traits and Idealistic Long Range Occupational Aspiration

Comparison of neuroticism and extraversion among institutionalized adolescent orphans with respect to:

1. GENDER

2. LOCALE

\section{GENDER}

Compare the difference between Neuroticism and Extraversion of Institutionalized Adolescent Orphans based on Gender

$\mathrm{H} 0$ : There is no significant correlation between Neuroticism and Extraversion of Institutionalized Adolescent Orphans based on Gender.

Table 2 Data and Result of Test of Significance between Neuroticism and Extraversion of Institutionalized Adolescent Orphans based on Gender

\begin{tabular}{ccccccc}
\hline Variables & Gender & N & M & SD & CR & $\begin{array}{c}\text { Level of } \\
\text { Significance }\end{array}$ \\
\hline Neuroticism & Boys & 125 & 52.65 & 6.79 & 7.843 & $\mathrm{P}<.05$ \\
& Girls & 125 & 61.31 & 10.32 & & \\
Extraversion & Boys & 125 & 61.23 & 7.04 & \multirow{2}{*}{4.044} & $\mathrm{P}<.05$ \\
& Girls & 125 & 57.02 & 9.26 & & \\
\hline
\end{tabular}

Table 2 shows that the obtained CR value is 7.843 and 4.044 are greater than the table value (1.65) at .05 level of significance. This means there is a difference between boys and girls in their Neuroticism and it can be concluded that the girls have high Neuroticism than Extraversion. Hence it is inferred that there is a 
Jyothy and Santhi Occupational Aspiration Skill and Personality Traits

significant correlation between Institutionalized adolescent boys and girls orphans in their Neuroticism and Extraversion

\section{LOCALE}

H0: There is no significant correlation between Neuroticism, and Extraversion of Institutionalized Adolescent Orphans based on Locale.

Table 3 Data and Result of Test of Significance between Neuroticism, and Extraversion of Institutionalized Adolescent Orphans based on Locale

\begin{tabular}{llllclc}
\hline Variables & Locale & $\mathrm{N}$ & $\mathrm{M}$ & $\mathrm{SD}$ & $\mathrm{CR}$ & $\begin{array}{c}\text { Level of } \\
\text { Significance }\end{array}$ \\
& Rural & 125 & 55.26 & 8.79 & & 2.76 \\
Neuroticism & Urban & 125 & 58.632 & 10.42 & & $\mathrm{P}<.05$ \\
& Rural & 125 & 59.82 & 8.24 & \multirow{2}{*}{1.199} & $\mathrm{P}>.05$ \\
\hline
\end{tabular}

Table 3 shows that the obtained CR vale is 2.76 is greater than the table value (1.65) at .05 level of significance. This means there is difference between Rural and Urban Orphans in their Neuroticism. It can be concluded that the rural orphans have low neuroticism compared to urban orphans. CR value of extraversion is 1.199.It indicates that there is no difference between rural and urban orphans in their extraversion. Hence it is inferred that there is no significant correlation between Rural and Urban Orphans in their Extraversion

The Comparison of Realistic Short-Range Career Aspiration, Idealistic Short-Range Career Aspiration, Realistic Long-Range Career Aspiration and Idealistic Long-Range Career Aspiration of Institutionalized Adolescent Orphans with regard to Gender and Locale is given below:

\section{GENDER}

H0: There is no significant correlation between boys and girls in component wise occupational aspiration skills 
Table 4 Data and Result of Test of Significance between Boys and Girls in the occupational aspiration of Institutionalized Adolescent Orphans.

\begin{tabular}{|c|c|c|c|c|c|c|}
\hline Variables & Gender & $\mathrm{N}$ & $\mathrm{M}$ & SD & CR & $\begin{array}{c}\text { Level of } \\
\text { Significance }\end{array}$ \\
\hline Realistic Short & Boys & 125 & 9.89 & 3.55 & & \\
\hline $\begin{array}{l}\text { Range Career } \\
\text { Aspiration }\end{array}$ & Girls & 125 & 11.84 & 3.599 & 4.32 & $\mathrm{P}<.05$ \\
\hline $\begin{array}{l}\text { Idealistic Short } \\
\text { Range Career }\end{array}$ & Boys & 125 & 9.13 & 3.70 & 2.19 & \\
\hline Aspiration & Girls & 125 & 10.21 & 4.08 & & $\mathrm{P}<.05$ \\
\hline Realistic Long & Boys & 125 & 8.85 & 3.49 & & \\
\hline $\begin{array}{l}\text { Range Career } \\
\text { Aspiration }\end{array}$ & Girls & 125 & 11.8 & 4.22 & 6.03 & $\mathrm{P}<.05$ \\
\hline Idealistic Long & Boys & 125 & 8.696 & 3.9 & & \\
\hline $\begin{array}{l}\text { Range Career } \\
\text { Aspiration }\end{array}$ & Girls & 125 & 12.43 & 4.7 & 6.87 & $\mathrm{P}<.05$ \\
\hline
\end{tabular}

Table 4 shows that the obtained CR value 4.32., 2.19, 6.03, 6.87 is greater than the table value (1.65) at .05 level of significance. This means that there is a difference between boys and girls in their Realistic Short Range Career Aspiration, Idealistic Short Range Career Aspiration, Realistic Long Range Career Aspiration, and Idealistic Long Range Career Aspiration. It can be concluded that the girls have high Realistic Short Range Career Aspiration, Idealistic Short Range Career Aspiration, Realistic Long Range Career Aspiration, and Idealistic Long Range Career Aspiration.

\section{Locale}

H0: There is no significant correlation between rural and urban orphans in component wise occupational aspiration skills 
Jyothy and Santhi Occupational Aspiration Skill and Personality Traits

Table 5 Data and Result of Test of Significance between Realistic Short Range Career Aspiration, Idealistic Short Range Career Aspiration, Realistic Long Range Career Aspiration, and Idealistic Long Range Career Aspiration of Institutionalized Adolescent Orphans based on Locale

\begin{tabular}{llllllc}
\hline \multicolumn{1}{c}{ Variables } & Locale & $\mathrm{N}$ & $\mathrm{M}$ & $\mathrm{SD}$ & $\mathrm{CR}$ & $\begin{array}{c}\text { Level of } \\
\text { Significa } \\
\text { nce }\end{array}$ \\
\hline $\begin{array}{l}\text { Realistic Short } \\
\text { Range Career }\end{array}$ & Rural & 125 & 11.04 & 3.62 & & \\
$\begin{array}{l}\text { Aspiration } \\
\text { Idealistic Short }\end{array}$ & Rurban & 125 & 16.69 & 3.77 & 0.7521 & $\mathrm{P}>.05$ \\
$\begin{array}{l}\text { Range Career } \\
\text { Aspiration, }\end{array}$ & Urban & 125 & 9.59 & 3.98 & & \\
$\begin{array}{l}\text { Realistic Long } \\
\text { Range Career }\end{array}$ & Rural & 125 & 9.74 & 3.89 & 0.289 & $\mathrm{P}>.05$ \\
$\begin{array}{l}\text { Aspiration } \\
\text { Idealistic Long } \\
\text { Range Career }\end{array}$ & Urban & 125 & 10.82 & 4.296 & 1.88 & $\mathrm{P}<.05$ \\
Aspiration & Urban & 125 & 10.26 & 4.69 & & \\
\hline
\end{tabular}

Table 5 shows that the obtained CR values $0.7529,0.289$, and 0.99 are lower than the table value (1.65) at .05 level of significance. This means there is no difference between Rural and Urban Orphans in their in Realistic Short Range Career Aspiration, Idealistic Short Range Career Aspiration, and Idealistic Long Range Career Aspiration.

The result suggests that there is a significant correlation between boys and girls in their Realistic Short Range Career Aspiration, Idealistic Short Range Career Aspiration, Realistic Long Range Career Aspiration, and Idealistic Long Range Career Aspiration. There is a difference between Rural and Urban Orphans in their Realistic Long Range Career Aspiration. The study result supported the assumption that majority of male orphans prefer professions like engineer, doctor, civil service etc. But female orphans prefer to take up professions like lawyer, teacher, nurse etc. The outcome of the result is that girls have more academic achievement than boys and show interpersonal and intrapersonal awareness and management. They are more extravert than boys and have a more realistic and idealistic career aspiration than boys. To grow in to self-esteemed and holistically developed adults, these female adolescents need more attention and protection. 
In this study the results also suggests that girls shows high initial and mature career points than boys. The individuals with high career points would live their education lives with goals, reliability, mature career plans, and circumspectness (Philip, Lenard, 1968). These adolescent orphans show self-confidence, and are highly motivated to work for target sets.

\section{Conclusion}

This study investigated the occupational aspiration skills and personality traits of institutionalized adolescent orphans with respect to their gender and locale. Understanding their long and short range career aspiration may have several implications for their personality development, particularly in the area of career setting. The findings revealed that institutionalized adolescent girls have better career aspirations than boys among the orphans. But it has nothing to do with the region. There is no significant relationship found between the aspiration of the rural and urban orphans. Teachers and administrators should take the responsibility to build mature career aspirations among adolescent orphans. Orphanage administrators should re-organize the existing evaluation system in such a way that it would improve orphan's career aspirations. Resource teachers with multi category training may be appointed to Orphanages.

\section{Implications of the Study}

1. Effective steps should be taken to improve the occupational aspiration of institutionalized adolescent orphans

2. Better facilities should be arranged in orphanages to enhance career aspiration

3. Better library facilities including reading materials, magazines and club activities should be provided to all orphanages.

4. Teachers and Administrators should find sufficient time to find out the individual ability of their students and give proper career guidance. 
Jyothy and Santhi Occupational Aspiration Skill and Personality Traits

5. Career Guidance should be included as a part of the academic curriculum.

\section{References}

Best, J.W. and Kahn, J.V. (1992). Research in Education (6 ${ }^{\text {th }}$ Ed.), New Delhi: Vikas Publishing House Private Limited.

Girija, B. (1989).A Study on the Psychological Needs and Vocational Aspiration of the Students in Vocational Higher Secondary Schools of Kerala, Unpublished M.Ed. Thesis, Thiruvananthapuram: University of Kerala.

Bhabley, B. (2001).Psychology an Introduction. London: McGraw Hill Publishing Company.

Betlow, M. B. (2005). The Effects of Social Skills Intervention on the Emotional Intelligence of Children with Limited Social Skills.

Kaur, D. (1990). Educational and Vocational Aspirations of Students Belonging to Different Socio-Economic Locales of Jammu Division. Journal of Research and Extension, 21.

Paul, K. (1979). A Comparative Study of the Psychological Needs and Problems of Resident and Non-resident Students of Secondary Schools of Kerala. Unpublished M. Ed. Thesis, Thiruvananthapuram: Kerala University.

Patton, W., \& Creed, P. (2007). The relationship between career variables and occupational aspirations and expectations for Australian high school adolescents. Journal of Career Development, 34(2), 127-148.

Uka, A. (2015). Students' Educational and Occupational Aspirations Predicted by Parents' and Adolescents' Characteristics. EJSER European Journal of Social Sciences Education and Research Articles, 4.

Pillay, H., Kelly, K., \& Tones, M. (2006). Career aspirations of older workers: an Australian study. International Journal of Training and Development, 10(4), 298-305.

Phillips, L. W. (1968). Occupational Choice and Vocational Interests. The journal of Educational research, 61(8), 355-359.

Millon, T. (1987). On the genesis and prevalence of the borderline personality disorder: A social learning thesis. Journal of personality Disorders, 1(4), 354-372.Hurlock B. Elizabeth (1995). Personality Development, New Delhi: Tata McGraw Hill Publishing Company Ltd.

Di Fabio, A., \& Palazzeschi, L. (2009). Emotional intelligence, personality traits and career decision difficulties. International Journal for Educational and Vocational Guidance, 9(2), 135-146. 